\title{
SENI REJUNG SEBAGAI SASTRA TUTUR ETNIK SEMENDE BERMUATAN NILAI BUDAYA LOKAL
}

\author{
Fadhilah Hidayatullah ${ }^{1)}$ \\ Dosen FKIP Program Studi Pendidikan Seni Pertunjukan, Universitas PGRI Palembang \\ Jl. Jend.A.Yani Lrg.Gotong Royong, 9/10 ulu Kota Palembang \\ Email : fadhilahhidayatullah@gmail.com
}

\begin{abstract}
This article discusses the results of research on Rejung art in Tanjung Bulan village, Pulau Beringin district (OKU Selatan). The background, the need to be studied and transformed towards regeneration. Because it is rich in local cultural values. The approach used in this research is qualitative with descriptive methods. The results of this study are that there are poems that contain the value of life containing messages; advice, moral, social, religious, and aesthetic. The purpose of this research was to determine the content of the art of rejung, both express and implied. The values contained are the values of local wisdom as a guide in character education. It is recommended that further research be carried out, so that it can be used as material for the world of education, especially at the elementary school level, as material for children's character education, because it contains the values of life with a local culture of Semende ethnicity. The art of rejung has local wisdom values contained in it. Its cultural values are more on the values of life. The value of life contained in the art of rejung which includes; values of trust and advice, moral values, religious values, and aesthetic values. The value of the mandate and advice that develops in rejung art poetry is conveyed through rejung art poetry with various titles and types of rhymes created by the artists. The mandate values contained in the lyrics are presented in the form of a vocal presentation with a variety of different kenjun. Then on the aesthetic value. The aesthetic value of the art of rejung is seen in the kenjun in each presentation. Kenjun is the rise and fall of the rejung art song melody. Kenjun can be interpreted as the value of beauty, because Semende's custom is a custom that is beautiful and peaceful, and full of affection. This is still related to the customary law rules adopted, because Semende's customary law is oriented towards Islam. His art also contains the values of life in accordance with Islamic law and law.
\end{abstract}

Keywords: Local Cultural, Values, Rejung Art.

\begin{abstract}
Abstrak
Artikel ini membahas hasil penelitian pada seni Rejung yang ada di desa Tanjung Bulan, Kecamatan Pulau Beringin (OKU Selatan). Dilatar belakangi, perlunya untuk dipelajari dan ditransformasikan terhadap regenerasi. Karena kaya akan nilai budaya lokal. Pendekatan yang digunakan dalam penelitian ini adalah kualitatif dengan metode deskriptif. Adapun hasil dari penelitian ini adalah terdapat syair yang memuat nilai kehidupan berisi pesan; nasihat, moral, sosial, relegi, dan estetik. Tujuan dilakukan penelitian ini adalah untuk mengetahui kandungan isi pada seni rejung, baik tersurat maupun tersirat. Nilai yang terkandung adalah nilai-nilai kearifan lokal sebagai pedoman dalam pendidikan karakter. Direkomendasikan agar ada penelitian lanjutan, sehingga dapat dijadikan sebagai materi untuk dunia pendidikan, khususnya ditingkat Sekolah Dasar, sebagai materi pendidikan karakter anak, karena memuat nilai-nilai kehidupan yang berbudaya lokal etnik Semende. Seni rejung memiliki nilai-nilai kearifan lokal yang terkandung di dalamnya. Nilai kebudayaannya yang lebih pada nilai-nilai kehidupan. Adapun nilai kehidupan yang terdapat pada seni rejung yang meliputi; nilai amanat dan nasihat, nilai moral, nilai religius, dan nilai estetis. Nilai amanat dan nasihat yang berkembang pada syair seni rejung yang disampaikan melalui syair seni rejung dengan berbagai judul dan jenis pantun yang diciptakan para senimannya. Nilai-nilai amanat yang terkandung melalui syair yang disajikan dalam bentuk sajian vokal dengan berbagai kenjun yang berbeda. Kemudian pada nilai estetis. Nilai estetis pada seni rejung yakni terlihat pada kenjun disetiap penyajiannya. Kenjun merupakan naik turunnya pada melodi lagu seni rejung. Kenjun tersebut dapat dimaknai pada nilai keindahan, karena adat Semende adalah adat yang indah dan damai, serta penuh dengan kasih sayang. Hal tersebut masih berhubungan dengan aturan hukum adat yang di anut, karena hukum adat Semende adalah berkiblat pada agama Islam. Keseniannya pun bermuatan nilai-nilai kehidupan sesuai dengan hukum dan syariat Islam.
\end{abstract}

Kata Kunci: Nilai, Budaya Lokal, Seni Rejung. 


\section{Pendahuluan}

Nilai budaya lokal lahir dari berbagai wilayah persebaran Suku dan Etnik bangsa. Seperti pada wilayah administratif Provinsi Sumatera Selatan terdiri dari keberagaman etnik dan budaya pula. Salah satunya adalah sastra yang dituturkan dari mulut ke mulut yang berkembang ditengah masyarakat. Sastra tutur merupakan seni sastra yang dituturkan di tengah masyarakat Sumatera-Selatan sejak beratus-ratus tahun lalu (Sembilan, Kobar., 2008, hlm. 1).

Sastra tutur lahir dari beragam etnik diwilayahnya, sehingga kaya akan budaya yang terdapat bahasa dengan karakter masing-masing setiap etnik. Salah satu etniknya yakni Semende, dengan dialek bahasa Semende. Sastra tutur yang ada di daerah wilayah provinsi Sumatera Selatan ini sudah termasuk aset budaya yang memang harus dilestarikan. Generasi muda harus memperhatikan, karena terkait pada pewarisan nilai budaya lokal yang sangat bermakna pada pembentukan karakter anak bangsa.

Salah satu seni yang bermula dari sastra tutur yakni seni rejung yang memiliki nilai-nilai kearifan lokal yang patut di ketahui dan di pedomani. Dengan demikian, penelitian ini fokus pada nilai budaya lokal Seni Rejung. Maka disusun pada pertanyaan sebagai berikut. "Bagaimana Nilai budaya lokal pada Seni Rejung yang ada di desa Tanjung Bulan Kecamatan Pulau Beringin (OKU Selatan)?.”

\section{Kajian Pustaka}

Soni Kartika, Dharsono dan Ganda Perwira, Nanang., (2004, hlm. 20) menyatakan bahwa Nilai adalah ukuran derajat tinggi-rendah atau kadar yang dapat diperhatikan, di teliti atau dihayati dalam berbagai objek yang bersifat fisik (kongkrit) maupun abstrak. Koentjaraningrat, (2009, hlm. 146), menyatakan bahwa kata budaya dapat juga sebagai suatu perkembangan dari kata majemuk budi-daya, yang berarti "daya dan budi". Karena itu mereka membedakan "budaya" dan "kebudayaan". Demikianlah "budaya" adalah "daya dan budi" yang berupa cipta, karsa dan rasa. Sedangkan "kebudayaan" adalah hasil dari cipta, karsa dan rasa itu. Istilah "antropologi-budaya" perbedaan itu ditiadakan. Kata "budaya" di sini hanya dipakai sebagai suatu singkatan saja dari "kebudayaan" dengan arti yang sama.

Kebudayaan merupakan pola tingkah laku yang dipelajari dan disampaikan dari satu generasi ke generasi berikutnya. Paling tidak, ada proses belajar kebudayaan yang penting, yaitu dalam kaitannya dengan manusia sebagai makhluk hidup, dan sebagai bagian dalam suatu sistem sosial. Proses belajar kebudayaan yang berlangsung sejak dilahirkan sampai mati, yaitu dengan kaitannya dengan pengembangan perasaan, hasrat, emosi dalam rangka pembentukan kepribadiannya; sering di kenal sebagai proses internalisasi. Karena makhluk manusia adalah bagian dari suatu sistem sosial, maka setiap individu harus selalu belajar mengenai pola-pola tindakan, agar ia dapat mengembangkan hubungannya dengan individu-individu lain disekitarnya (Poerwanto, 2000, hlm. 88).
Sebagian besar para ahli antropologi sepakat bahwa kebudayaanlah yang telah membentuk makhluk manusia, dan bukan alam sekitarnya. Keberhasilan mereka mendudukkan alam sekitarnya adalah bukti keberhasilan mereka mencapai suatu tingkat kebudayaan yang lebih tinggi. Makhluk manusia selalu berupaya untuk menyesuaikan dirinya dengan berbagai perubahan yang terjadi di sekitarnya sehingga melahirkan suatu pola-pola tingkah laku yang baru. Oleh karena lingkungan alam berbeda-beda, maka terdapat berbagai bentuk adaptasi dikalangan makhluk manusia. Kemajuan ilmu pengetahuan yang dimilikinya, mampu merubah alam sekitarnya, dan akhirnya perubahan-perubahan yang ditimbulkannya akan selalu di arahkan kepada makhluk manusia (Poerwanto, 2000, hlm. 87).

Sistem nilai budaya merupakan tingkat yang paling tinggi dan paling abstrak dari adat istiadat. Hal tersebut disebabkan karena nilai budaya merupakan konsep-konsep mengenai sesuatu yang ada dalam alam fikiran, sebagian besar dari masyarakat yang mereka anggap bernilai, berharga, dan penting dalam hidup sehingga dapat berfungsi sebagai suatu pedoman yang memberi arah dan orientasi pada kehidupan para warga masyarakat (Koentjaraningrat, 2009, hlm. 153).

Sejalan dengan konsep yang dikemukan Sumardjo, Jakob (2000, hlm. 140). Konsepnya yang berkaitan pada komponen nilai yang terdapat pada seni. Namun penulis menginterpretasikan, dan menghubungkan dengan nilai yang terkandung dalam seni rejung. Berdasarkan hasil dari interpretasi konsep (Sumardjo, Jakob) tersebut, maka nilai pada seni rejung terdapat nilai amanat dan nasihat, moral, sosial, religi, dan estetik.

\section{Metode Penelitian}

Penelitian ini menggunakan metode deskriptif kualitatif, sehingga data yang diperoleh akan dideskripsikan. Metode deskriptif adalah "suatu metode dalam pencarian fakta status kelompok manusia, suatu objek, suatu kondisi, suatu sistem pemikiran ataupun suatu peristiwa pada masa sekarang dengan interprestasi yang tepat (Sudarmayanti, dkk., 2002: 33)."

Adapun data didapatkan dengan melalui observasi, wawancara dan dokumentasi terhadap para pelaku dan tokoh budayawan setempat. Sedangkan teknik yang dilakukan yakni dengan cara merekam audio dan video, serta membuat catatan penting dari seluruh data yang di anggap penting. Senada dengan yang dikemukakan oleh Poham (dalam Prastowo, 2011: 208) bahwa "teknik pengumpulan data adalah cara yang di pakai untuk mengumpulkan informasi." Kemudian juga sebagai langkah yang paling strategis dalam penelitian karena tujuan utama penelitian adalah mendapatkan data (Sugiyono dalam Prastowo, 2011: 208).

Seluruh data yang di dapat, dilakukan analisa dengan cara mendengarkan dan melihat dalam kegiatan analisa, kemudian di tuliskan dalam sebuah tulisan yang mengacu pada jawaban rumusan permasalahan. Dengan demikian, data dapat dihasilkan dan disajikan dalam kalimat deskriptif kualitatif. 


\section{Pembahasan}

Berdasarkan hasil penelitian yang dilakukan melalui observasi, wawancara dan dokumentasi, diperoleh datadata yang akan di deskripsikan sedemikian rupa. Adapun hasil gabungan percakapan peneliti dengan informan yakni Bapak H.Ahmad Kordin (2020) yang lalu, sehingga diinterpretasikan sebagai berikut.

Seni rejung memiliki nilai-nilai kearifan lokal yang terkandung di dalamnya. Nilai kebudayaannya yang lebih pada nilai-nilai kehidupan. Adapun nilai kehidupan yang terdapat pada seni rejung yang meliputi; nilai amanat dan nasihat, nilai moral, nilai religius, dan nilai estetis.

Nilai amanat dan nasihat yang berkembang pada syair seni rejung yang disampaikan melalui syair seni rejung dengan berbagai judul dan jenis pantun yang diciptakan para senimannya. Nilai-nilai amanat yang terkandung melalui syair yang disajikan dalam bentuk sajian vokal dengan berbagai kenjun yang berbeda. Adapun contoh dari syair yang memuat nilai amanat tersebut yakni sebagai berikut.

\section{Dialek Etnik Semende: \\ 1. Perenggi pegi di gulai, \\ 2. Seluang campur stumbar idup; \\ 3. Kah pegi rupu'i kudai, \\ 4. Kalu nesalan seumur idup;}

Terjemah Dalam Bahasa Indonesia:

1. perenggi boleh di masak,

2. ikan seluang dicampur setumbar hidup;

3. mau pergi pikirkan dahulu,

4. takut menyesal seumur hidup;

Berdasarkan pantun tersebut, terdapat hal yang disampaikan. Adapun yang disampaikan melalui syair seni rejung tersebut yakni berupa nasihat dari unsur berhati-hati dalam melakukan sesuatu. Sebelum bertindak harus benar-benar mematangkan pemikiran terlebih dahulu, agar tidak merugikan diri sendiri dan orang-orang terdekat.

Selain itu, terdapat pula nilai-nilai yang bermuatan pada hukum dan aturan-aturan adat istiadat. Pesan di dalamnya terkait dari moral yakni pesan ajakan untuk kebaikan. Segala bentuk ajakan yang masih berhubungan pada semua hal kebaikan. Pesan yang disampaikan tersebut tersirat maupun tersurat dalam bentuk sajian yang kompleks pada seni rejung.

Pesan yang tersirat membutuhkan pemahaman ulang terhadap isi syair yang disampaikan. Sedangkan yang tersurat menggunakan kalimat yang langsung ke titik yang hendak disampaikan. Umumnya, bersifat jelas dan lebih pamiliar, serta mudah dimengerti oleh semua orang. Contoh dari syair seni rejung yang memuat nilainilai moral tersebut, di ilustrasikan sebagai berikut.

\section{Dialek Etnik Semende: \\ 1. Likati gule dalam belange, \\ 2. Belange ade baling papan; \\ 3. Adat kite adat semende,}

4. Adat nggak ghukum seghempak jalan;

Terjemah Dalam Bahasa Indonesia:

1. rekatkan gula dalam kuali,

2. kuali ada dibelakang papan;

3. adat kita adat semende,

4. adat dan hukum seiringan berjalan;

Berdasarkan pantun tersebut, terdapat hal yang disampaikan. Pesan yang terkandung di dalam syair tersebut menunjukkan bahwa suku etnik Semende sangat mulia dalam aturannya. Mulia nya ajaran pada adat istiadat Etnik Semende karena mengacu dan mempedomani pada ajaran Agama yang di anutnya yakni agama Islam. Melalui nilai yang disampaikan pada syair tersebut, bahwa Aturan adat dan etnik Semende sangat beriiringan terhadap ajaran dan syariat Islam.

Setelah menggambarkan nilai dari moral yang terdapat pada syair tersebut, di lanjutkan pada nilai-nilai syair seni rejung yang bersifat religius. Berdasarkan keyakinan yang di anut oleh masyarakat Semende yakni Agama Islam, sehingga syair dari rejung pun berkembang sebagai media dalam menyampaikan pesan yang bersifat religi. Syair yang berbentuk pantun pada seni rejung terdapat berbagai macam pesan yang disampaikan, menyangkut pada nilai religi. Mulai dari teguran yang bersifat kalimat perumpamaan maupun secara kalimat terang-terangan. Adapun contoh dari syair yang memuat nilai religi tersebut yakni sebagai berikut.

Dialek Etnik Semende:

1. Asam kandis asam lenggugur,

2. Ke tige asam riang-riang;

3. Badan menangis di pintu kubur,

4. Tehingat badan dik sembayang;

Terjemah Dalam Bahasa Indonesia:

1. Asam kandis asam lenggugur,

2. Ketiga asam riang-riang;

3. Badan menangis di pintu kubur,

4. Teringat badan tidak sembahyang;

Berdasarkan pantun tersebut, terdapat hal yang disampaikan. Sebelum menguraikan makna yang terdapat pada syair pantun tersebut, terlebih dahulu dijelaskan terkait kata-kata asing yang terdapat pada pantun tersebut. Kandis, dan lenggugur merupakan jenis tumbuhan, yang biasanya untuk masam. Fungsinya sama dengan tomat untuk bumbu sayur.

Pesan yang terkandung melalui syair tersebut yakni bahwa seseorang yang penuh dengan tangisan penyesalan di alam barzah (kubur), karena semasa hidupnya tidak melaksanakan rukun Islam yaitu Sholat. Dengan demikian bahwa, di dalam syair tersebut terdapat nilai pesan religi yang sangat berharga dan menjadi pembelajaran untuk menyiapkan sebelum tiba pada waktunya.

Kemudian pada nilai estetis. Nilai estetis pada seni rejung yakni terlihat pada kenjun disetiap penyajiannya. Kenjun merupakan naik turunnya pada 
melodi lagu seni rejung. Kenjun tersebut dapat dimaknai pada nilai keindahan, karena adat Semende adalah adat yang indah dan damai, serta penuh dengan kasih sayang. Hal tersebut masih berhubungan dengan aturan hukum adat yang di anut, karena hukum adat Semende adalah berkiblat pada agama Islam. Keseniannya pun bermuatan nilai-nilai kehidupan sesuai dengan hukum dan syariat Islam. Dengan demikian, nilai-nilai budaya yang terdapat pada kesenian rejung, sangat berarti pada kehidupan dimasyarakatnya. Namun apabila masyarakatnya memandang dari kulitnya saja, maka tidak akan sampai pada nilai yang terkandung di dalamnya.

Pesan yang disampaikan melalui syair pantun yang ditembangkan bersifat "dikde asak gerugas". Hubungan antara istilah tersebut yakni bahwa di dalam syair seni rejung selalu di awali oleh perumpamaanperumpamaan kata yang terdapat di dalam syairnya. Di awali dengan baris satu dan dua tersebut lah sebagai kategori dikde asak gerugas. Maksud dari istilah tersebut adalah tidak langsung ke inti permasalahan. Pada umumnya, syair satu dan dua merupakan gambaran umum atau awalan menuju baris tiga dan empat pada pantun. Setelah itu dilanjutkan pada isi yang sebenarnya yakni baris tiga dan empat.

Berdasarkan nilai-nilai budaya etnik Semende yang terdapat pada kesenian rejung tersebut, di pandang perlu untuk ditransformasikan terhadap generasi. Hal tersebut dilakukan baik diwilayah itu maupun di masyarakat luas, sehingga nilai budayanya tetap tersalurkan pada genarasi penerusnya. Nilai-nilai kehidupan yang mencerminkan kebudayaan dan jati diri bangsa tetap terjaga dan lestari, sehingga dapat menjadi sebagai pondasi karakter anak bangsa.

Nilai merupakan ukuran yang dilihat dari hasil yang terkandung dalam sebuah objek seni. Objek seni mengandung nilai yang sangat bermakna. Seperti yang di ungkap oleh Soni Kartika, D., dan Ganda Perwira, N., yang menyatakan nilai merupakan sebuah ukuran derajat tinggi dan rendahnya suatu kadar yang terdapat di dalamnya. Nilai tersebut tergambar sebagai ukuran dari derajat suatu objek seni. Melalui nilai tersebut yang terkandung dalam objek seni yakni pada seni rejung. Rejung merupakan suatu objek seni yang diciptakan oleh pakar terdahulu yang tidak diketahui identitasnya. Mereka menciptakan seni rejung dengan mengutamakan pada syair yang berbentuk pantun.

Syair yang diciptkan oleh seniman terdahulu yakni pantun yang menggunakan dialek etnik Semende. Pantun tersebut diciptakan sesuai dengan kepentingan sesaat, tanpa dihapal dan perencanaan yang panjang. Pantun yang diciptakan bersamaan dengan komunikasi yang hendak disampaikan sesuai dengan waktunya. Pantun-pantun yang di utarakan melalui mulut mereka merupakan suatu kalimat yang menyampaikan perumpamaan-perumpamaan yang disampaikan melalui kalimat yang berbentuk pantun. Syair yang dilantunkan tersebut, sebagai ungkapan seseorang dalam menyampaikan maksud dan tujuannya.
Terkait syair yang diciptakan oleh seniman terdahulu berbentuk pantun yang berfungsi untuk menyampaikan pesan. Selain itu, pesan yang dikomunikasikan bukan saja pesan biasa. Pesan yang disampaikan juga berfungsi dalam menyampaikan maksud terhadap perasaan dengan lawan jenis. Hal tersebut juga dilakukan oleh masyarakat etnik Semende terdahulu. Penyampaian atau tuturan rejung tersebut tentunya belum mengenal dengan penyajiannya yang kompleks. Penyajian yang kompleks maksudnya adalah penyajian yang sudah terbentuk dalam lagu.

Hal tersebut mengalami pergeseran fungsi yakni pada hiburan. Sebagai hiburan juga berkenaan dengan penyajian yang dilakukan. Penyajiannya dapat dilakukan dengan menyanyikan yang diiringi dengan instrumen musik. Namun hal tersebut sudah mengalami pergeseran pada pantun-pantun yang lebih menghibur. Pantun yang menghibur tersebut masih memiliki pesan yang disampaikan. Pesan yang disampaikan melalui seni rejung tersebut bersifat tersirat dan tersurat.

Pesan yang disampaikan melalui seni rejung yang bersifat tersirat terdapat pada pantun-pantun lama. Melalui pesan yang bersifat tersirat tersebut masih perlu dikaji lebih dalam, terkait makna dan pesan yang disampaikan. Syair yang bersifat tersebut biasanya diilustrasikan dengan syair yang penuh dengan perumpamaan-perumpamaan. Kalimat yang digunakan dalam syair seni rejung tersebut terkait pada seputaran alam. Seputaran alam tersebut yakni pada seluruh ciptaan yang Maha Kuasa. Setiap suku kata yang digunakan dalam menyampaikan dengan perumpamaanperumpamaan yang termuat suku kata tumbuhan, hewan, dan lain sebagainya.

Berdasarkan setiap suku kata yang terbentuk menjadi sebuah kalimat dalam pantun, menggunakan nama-nama hewan, tumbuhan, atau yang lainnya terdapat makna yang tersirat. Makna yang dipetik dalam setiap suku kata tersebut adalah semua yang ada di alam pasti ada yang menciptakan. Dengan demikian bahwa, bukti adanya hewan, tumbuhan, dan makhluk lainnya menunjukkan adanya Allah, Swt.

Setiap suku kata yang sangat sering menggunakan makhluk ciptaanNya, dapat juga di analogikan bahwa hidup ini selalu berdampingan dengan makhluk ciptaan Allah lainnya. Dengan demikian bahwa syair yang tercipta sesuai dengan lingkungan yang ada. Lingkungan yang mengelilingi pada pola fikir masyarakat etnik Semende yakni Alam yang masih alami. Hal tersebut juga mengandung nilai yang sangat bermakna. Nilai yang terkandung di dalamnya adalah kasih sayang terhadap lingkungan alam yang ada.

Selain itu pula, terdapat pesan tersurat yang disampaikan. Pesan tersurat disampaikan mengandung nilai-nilai kehidupan yang memang patut dipedomani. Namun berbeda dengan pesan tersirat yang telah di ungkap sebelumnya. Melalui pesan yang tersurat di ilustrasikan dengan jelas, meskipun masih terdapat katakata yang sulit dipahami. Hal tersebut disebabkan karena bahasa yang digunakan sudah banyak ditinggalkan oleh masyarakat sekitar. Sehingga wajar saja kalau ada 
kalimat di dalam syair tersebut mengalami kesulitan dalam menemukan arti dan maknanya.

Pesan yang disampaikan melalui syair seni rejung tersebut terdapat nilai-nilai kehidupan, seperti yang diungkap oleh Sumardjo, Jakob. Nilai-nilai yang terkandung dalam seni rejung lebih cenderung pada nilai kehidupan. Melalui syair yang terkandung di dalam syair seni rejung mengandung nasihat, moral, sosial, relegi, dan estetik. Melalui pesan-pesan yang disampaikan pada nilai-nilai yang sepatutnya dipedomani oleh masyarakat sekitarnya. Hal yang disampaikan tersebut seiringsejalan dengan aturan adat dan syariat Islam.

Berkaitan hal tersebut karena masyarakat etnik Semende mayoritas memeluk agama Islam. Berdasarkan para pakar seniman seni rejung mengutarakan bahwa adat Semende juga mempunyai makna. Kata Semende tersebut dapat di jelaskan sebagai berikut. Kata "Semende" diklasifikasikan sebagai berikut: $/ \mathrm{se} /, \mathrm{lm} /$, dan /ende/, sehingga terbentuk kata "Semende". Apabila dikaji, maka /se/ pada bahasa dialek Semende dimaknai dengan satu. Kemudian huruf $/ \mathrm{m} /$ dimaknai dengan Muhammad, sedangkan kata lendel dimaknai dengan kepunyaan. Berdasarkan kata Semende tersebut dapat ditemukan makna yang tersirat yakni Allah, Muhammad, adalah kepunyaanku. Dengan demikian bahwa, nama dari etnik Semende mencerminkan adat dan suku yang berkiblat pada ajaran Islam.

Berdasarkan hal tersebut, maka wajar saja dalam seni rejung terdapat nilai-nilai kehidupan yang mencerminkan ajakan-ajakan kebaikan serta ajaranajaran dalam beragama sesuai dengan syariat Islam. Berkenaan hal tersebut para pakar di Wilayah Semende juga mengatakan bahwa adat Semende didirikan oleh Puyang Awak (orang yang di tuakan dan dihormati atas semua ajarannya). Sekaitan Puyang Awak tersebut, sebagian masyarakat etnik Semende meyakininya sebagai wali Allah, diluar dari struktur Wali Songo, dan ada juga yang meyakini sebagai nama lain dari Syekh Siti Jenar. Namun yang dikenal oleh masyarakat di Wilayah Semende yakni dengan sebutan Puyang Awak. Berdasarkan dari penjelasan yang di peroleh dari para pakar Budaya di Wilayah etnik Semende, bahwa sebutan Puyang Awak tersebut yakni dengan nama asli "Syekh Baharuddin Nurqadim".

Kemudian, melalui pesan yang disampaikan pada seni rejung juga menggambarkan betapa sederhananya masyarakat diwilayah itu. Kesederhanaan tersebut dapat diperdengarkan pada irama yang digunakan terdapat pengulangan disetiap baris pantunnya. Disetiap baris ganjil pada pantun yakni baris satu dan tiga hanya menggunakan satu irama. Demikian juga pada baris genap pantun yakni baris dua dan empat menggunakan irama yang sama. Irama pada seni rejung hanya terdiri dari dua jenis saja. Kedua irama tersebut mewakili dari keempat baris pantun.

Irama yang dilantunkan tersebut sebagai nilai estetis yang terkandung dalam seni rejung. Selain itu, menggambarkan kesederhanaan terdapat pada masyarakat diwilayah itu. Pola hidup sederhana memang dianjurkan dan berlaku pada kehidupan masyarakat
Semende. Disamping itu pula tergambar bahwa masyarakat etnik Semende saling menghormati. Saling menghormati tersebut ditunjukkan dengan sikap saat menyampaikan sesuatu selalu di dahului dengan perumpamaan-perumpaan sebelum memasuki pada inti yang mau disampaikan.

Makanya di dalam masyarakat etnik Semende dikenal dengan istilah dikde asak gerugas. Istilah tersebut artinya di dalam melakukan sesuatu harus berupa awalan dan penghantar. Dikaitkan pada seni rejung terdapat pada syair baris nomor satu dan dua. Syair tersebut penuh dengan perumpamaanperumpamaan. Kendati pun kalimat tersebut mempunyai makna, namun hal tersebut merupakan penghantar di dalam menyampaikan yang seutuhnya. Berdasarkan hal tersebut telah tergambar bahwa sikap saling menghargai dan sikap sopan santun dalam bertutur sapa.

Melalui hal-hal yang dapat ditemukan dalam seni rejung banyak sekali nilai-nilai kehidupan sebagai cerminan dalam berkehidupan yang baik. Seni rejung yang mengandung nilai-nilai kehidupan sebagai pewarisan nenek moyang terdahulu. Karena tokoh dan pendiri dari etnik Semende adalah salah satu Tokoh penyebar Agama Islam, sehingga segala bentuk ajaran dan kebudayaan termuat di dalam seni rejung. Seni rejung juga sebagai perkembangan dari seni tutur (oral). Diwilayah etnik Semende dikenal dengan meratap. Meratap merupakan gumaman yang penuh dengan penyesalan. Didalam pelaksanaannya dilakukan dengan tuturan yang lepas dengan tidak beraturan, artinya tuturannya dengan irama sesuai dengan penjiwaannya saja.

Hal tersebut dapat dilakukan pada saat anggota keluaga yang meninggal. Berkenaan itu, setelah masuknya Agama Islam, ratapan tersebut mulai ditinggalkan oleh masyarakat di wilayah itu, karena di larang dalam agama Islam. Melalui kesenian rejung terdapat perkembangan dari irama ratapan. Dengan demikian, bahwa irama yang terdapat pada ratapan terdapat pada salah satu jenis seni rejung yang masih berkembang. Irama dengan sajian tersebut lebih pada kesan kesedihan. Namun syair-syair yang terdapat pada penyajiannya terdapat nilai-nilai yang patut di pedomani. Karena syairnya terdapat nilai-nilai kehidupan yang termuat makna "tidak baik menyesali yang sudah terjadi, karena ketentuan hanya milik Allah, Swt semata".

Melalui kesenian rejung banyak sekali nilai-nilai yang terkandung di dalamnya. Nilai yang termuat di dalamnya bersifat tersirat maupun tersurat. Namun pesan tersirat jauh lebih banyak dibandingkan pada pesan yang bersifat tersurat. Oleh sebab itu, kesenian rejung merupakan pewarisan budaya lokal yang berkembang di Wilayah Provinsi Sumatera Selatan. Kesenian tersebut kaya dengan nilai-nilai kearifan lokal sebagai pedoman dalam pendidikan karakter.

\section{Kesimpulan}

Nilai budaya lokal yang terkandung dalam seni rejung memuat nilai-nilai kehidupan. Nilai tersebut termuat dalam syair dan irama yang menyatu dalam seni 
rejung. Melalui nilai yang disampaikan tersebut terdapat nasihat, moral, sosial, relegi, dan estetik. Semua nilai yang termuat dalam seni rejung tersebut menyatu dalam seni rejung. Melalui syair menyampaikan pesan tersurat maupun tersirat yang harus dimaknai dengan baik, sehingga diperoleh hal yang positif untuk dipedomani. Segala bentuk nilai yang terkandung di dalamnya termuat pada syair seni rejung, demikian juga melalui irama terdapat pesan tersirat, yang menganalogikan kehidupan pada gaya kesederhanaan. Semua hal yang dimuat dalam syair dan irama terkandung nilai tersurat dan tersirat yang harus dimaknai dengan baik, sehingga nilai yang terkandung sangat penting untuk dipedomani.

\section{Daftar Pustaka}

Koentjaraningrat. (2009). Pengantar Ilmu Antropologi. Edisi Revisi. Jakarta: Rineka Cipta.

Poerwanto, Heri. (2000). Kebudayaan dan Lingkungan dalam Persepektif Antropologi. Yogyakarta: Pustaka Pelajar Offset.

Prastowo, Andi. (2011). Metode Penelitian Kualitatif dalam Perspektif Rancangan Penelitian. Jogjakarta: Ar-ruzz Media.

Sembilan, Kobar. (2008). Sastra Tutur di Kabupaten Ogan Komering Ilir: Dinas Pendidikan Provinsi Sumatera Selatan.

Soni Kartika, Dharsono \& Ganda Perwira, Nanang. (2004). Pengantar Estetika. Bandung: Rekayasa Sains.

Sudarmayanti, dkk. (2002). Metode Penelitian. Bandung: CV. Mandar Maju.

Sumardjo, Jakob. (2000). Filsafat Seni. Bandung: ITB.

\section{Narasumber :}

Ahmad Kordin (70), Seniman Rejung dan Tokoh Masyarakat Semende, Dusun Tanjung Bulan Kecamatan Pulau Beringin Kabupaten OKU Selatan. 